\title{
МЕДИАЦИЯ КАК СПОСОБ УРЕГУЛИРОВАНИЯ КОНФЛИКТОВ, ВОЗНИКАЮЩИХ В ОБЛАСТИ ЗДРАВООХРАНЕНИЯ: ПРОБЛЕМЫ И ПЕРСПЕКТИВЫ РАЗВИТИЯ
}

\author{
(c) 2021 Иванова Татьяна Михайловна \\ старший преподаватель кафедры теории и истории государства и права \\ Астраханский государственный университет, Россия, Астрахань \\ E-mail:krohmalt@mail.ru \\ (c) 2021 Радван Лэйла Мохамед \\ врач гастроэнтеролог дневного стационара \\ ГБУЗ АО «Городская поликлиника № 8 им. Н.И.Пирогова», Россия, Астрахань \\ E-mail:vradvan@mail.ru \\ (c) 2021 Фастова Марина Андреевна \\ кандидат юридических наук, доцент кафедры гражданского права \\ Астраханский государственный университет, Россия, Астрахань \\ E-mail: romanenkoma82@mail.ru
}

В статье рассматриваются проблемные вопросы, касающиеся охраны здоровья, поскольку они являются первостепенными для любого человека. В последние годы правовые конфликты в сфере медицины стали благодатной почвой для развития медиации в здравоохранении.

Основной целью исследования является рассмотрение проблем и перспектив медиации как способа урегулирования конфликтов, возникающих в области здравоохранения.

Ключевые слова: Медиация, охрана здоровья, посредничество, конфликты в сфере здравоохранения.

Важнейшим социальным правом человека и гражданина является право на охрану здоровья. Именно это неотчуждаемое благо человека провозглашается ст. 41 Конституции РФ, которая гарантирует право на охрану здоровья и медицинскую помощь [1]. Архиважность данного положения объясняется, прежде всего, тем, что в случае наступления последствий нарушения указанного права, практически утрачивают свое значение иные блага, принадлежащие человеку.

Признавая значимость и неоспоримость права на охрану здоровья и медицинскую помощь, Российская Федерация гарантирует гражданам создание всех условий для его реализации. Жизненно важные вопросы, касающиеся охраны здоровья являются первостепенными для любого человека. Поскольку в этих сферах нередко возникают чрезмерные эмоции, то довольно часто приходится сталкиваться с недовольством людей, а, следовательно, с высоким уровнем конфликтности. В связи с этим в последние годы правовые конфликты в сфере медицины стали благодатной почвой для развития медиации в здравоохранении, что обуславливает актуальность заявленной темы.
Цель исследования заключается в рассмотрении и анализе медиации как способа урегулирования конфликтов в сфере здравоохранения.

Методологическую основу исследования составляют такие общенаучные методы познания как анализ, системный подход, диалектический подход,метод индукции, атакжечастно-научный метод исследования - историко-правовой. Кроме того, используется особый методологический подход- структурный функционализм, позволяющий рассмотреть медиацию в сфере здравоохранения как сложную структуру, элементы которой в ходе социального взаимодействия выполняют различные функции, позволяющие сохранить стабильность социальной системы.

Важнейшим социальным правом человека и гражданина является право на охрану здоровья. Именно это неотчуждаемое благо человека провозглашается ст. 41 Конституции РФ, которая гарантирует право на охрану здоровья и медицинскую помощь. Архиважность данного положения объясняется, прежде всего тем, что в случае наступления последствий нарушения указанного права, практически утрачивают свое значение иные блага, принадлежащие человеку. 
Признавая значимость и неоспоримость права на охрану здоровья и медицинскую помощь, Российская Федерация гарантирует гражданам создание всех условий для его реализации. Так, государство разрабатывает и внедряет в жизнь комплекс мер, направленных на сохранение и укрепление здоровья, профилактику заболеваний, предупреждение возникновения и распространения заболеваний. Кроме того, создание и функционирование подобной эффективной системы, гарантирующей охрану здоровья граждан, обеспечивает всестороннее развитие личности человека.

В настоящее время в Российской Федерации правовой статус процедуры медиации (альтернативной процедуры урегулирования споров с участием посредника) определен Федеральным законом «Об альтернативной процедуре урегулирования споров с участием посредника (процедуре медиации)» от 27.07.2010 N 193-Ф3 (в ред. Федеральных законов от 02.07.2013 N 185-Ф3, от 23.07.2013 N 233-Ф3, от 26.07.2019 N 197-Ф3) [2]. В соответствии со ст. 2 указанного выше закона процедура медиации определяется как способ урегулирования споров при содействии медиатора на основе добровольного согласия сторон в целях достижения ими взаимоприемлемого решения.

Сложно не согласиться с мнением доцента, заведующей кафедрой гражданско-правовых дисциплин Алтайского филиала Российской академии народного хозяйства и государственной службы при Президенте РФ Н.И. Минкиной, что система здравоохранения нуждается в медиации. Более того, социологический опрос, проведенный среди врачей и медицинских сестер ГБУЗ АО «ГП № 8 им. Н.И. Пирогова» свидетельствует о готовности медицинских работников применять процедуру медиации (положительный ответ был получен у ста процентов опрашиваемых).

Процедура медиации при разрешении споров между медицинскими организациями и пациентами, равно как и в другой сфере, предполагает взаимное волеизъявление сторон и базируется на общих принципах альтернативной процедуры урегулирования споров с участием посредника, являющимися ориентирами для проведения процедуры медиации. В соответствии со ст. 3 Федерального закона от 27.07.2010 N 193-Ф3 (ред. от 26.07.2019) «Об альтернативной процедуре урегулирования споров с участи- ем посредника (процедуре медиации)» к ним относятся принцип добровольности; принцип конфиденциальности; принцип сотрудничества и равноправия сторон; принцип беспристрастности и независимости медиатора.

Процедура медиации в здравоохранении является добровольной, что предполагает желание сторон достичь справедливого соглашения. Учитывать необходимо и факт недопустимости принуждения к участию в процессе медиации. Более того, участник процедуры имеет право выйти из процесса медиации на любом этапе. Указанные выше положения позволяют сделать вывод об исполнении сторонами медиативного соглашения на основе принципов добровольности и добросовестности.

При проведении процедуры медиации медиатор не должен разглашать ход и результаты медиации. Однако, принцип конфиденциальности может быть нарушен в случае, прямо предусмотренном действующим законодательством.

Применение процедуры альтернативной процедуры урегулирования споров с участием посредника возможно только в отношении тех ситуаций, в которых стороны равны, и, следовательно, не имеют процедурных преимуществ. При этом медиатор не должен ставить одну из сторон в преимущественное положение.

Проведение процедуры медиации требует от медиатора беспристрастности. Ему необходимо построить свою работу на основании независимости от предубеждений. В случае обнаружения потенциальных собственных интересов, медиатор обязан прекратить процедуру медиации.

Следует иметь ввиду, что особенности применения процедуры медиации (примирения) базируются на специфике медицинской деятельности. Спектр участников конфликта в сфере здравоохранения достаточно обширен и включает в себя пациентов, родственников пациента, лечащего врача, коллег лечащего врача, экспертов, медицинский персонал и персонал обслуживания, руководителя лечебного учреждения, а также организации, связанные с лечебным учреждением (страховые и фармацевтические компании, контролирующие организации и т.д.). Кроме того, можно выделить отсутствие достаточных навыков разрешения конфликтов, а также морально-этические принципы в отношениях врача и пациента, которые формировались много веков назад.

Следует особо подчеркнуть, что медиацию 
в здравоохранении необходимо развивать не только с целью защиты прав пациентов, но и интересов медицинских работников.

С целью разрешения споров между медицинскими организациями и пациентами в медицинских организациях и ВУЗах страны целесообразно более активное внедрение института центра медиации (примирения) по разрешению медицинских споров. Деятельность подобных структурных единиц должна быть направлена, прежде всего, на организацию процедуры медиации по спорам, возникающим между медицинскими организациями и пациентами, на основании претензий пациентов к качеству оказанных медицинских услуг, ненадлежащему оказанию или неоказанию медицинской помощи и причинения в результате этого вреда. В целях подготовки медицинских медиаторов из числа сотрудников и обучающихся университета, а также медицинских работников необходимо проведение семинаров-тренингов, лекций. Особого внимания в этом вопросе заслуживает тот факт, что советский и российский педиатр и хирург, общественный деятель, профессор Л. М. Ро- шаль является руководителем инициативной группы Национальной медицинской палаты по изучению опыта врачебной палаты Германии, в результате чего были организованы первые конференции по вопросам применения альтернативной процедуры урегулирования споров с участием посредника в здравоохранении.

На наш взгляд, действенным решением может послужить внедрение в программу обучения студентов в медицинских вузах дисциплину «Медиация в системе здравоохранения», повышение квалификации медицинских работников по направлению по программам, связанным с применением процедуры медиации.

Для более активного внедрения института медиации в целях решения конфликтных ситуаций предлагается более активно внедрять данный институт в лечебные учреждения и медицинские ВУЗы страны. Способствовать этому может подготовка медицинских медиаторов из числа сотрудников и обучающихся университета, а также медицинских работников, проведение семинаров-тренингов, лекций и т.п.

\section{Библиографический список}

1. Конституция РФ// Российская газета - Федеральный выпуск № 144(8198).

2. Федеральный закон «Об альтернативной процедуре урегулирования споров с участием посредника (процедуре медиации)» от 27.07.2010 N 193-ФЗ (в ред. Федеральных законов от 02.07.2013 N 185-ФЗ, от 23.07.2013 N 233-ФЗ, от 26.07.2019 N 197-Ф3) // Российская газета от 30 июля 2010 г.- Федеральный выпуск № 168 (5247).

3. Федеральный закон от 29 ноября 2010 г. N 326-Ф3 «Об обязательном медицинском страховании в Российской Федерации» // Российская газета. 3 декабря 2010 - Федеральный выпуск № 274(5353).

4. Федеральный закон «Об основах охраны здоровья граждан в Российской Федерации» от 21.11.2011 N $323-$ Ф3 (с изм., внесенными Постановление КС РФ от 13.01.2020 N 1-П// Собрании законодательства Российской Федерации от 28 ноября 2011 г. N 48 ст. 6724.

5. Иванова Т.М. Фастова М.А. Посредничество в зарубежных государствах при разрешении правовых конфликтов: теоретико-правовой аспект// Вопросы экономики и права. - 2020._№ 6 (144). - C. 7-11.

6. Минкина Н.И. Медиация как способ урегулирования конфликтов, возникающих из правоотношений в области здравоохранения [Электронный ресурс] // URL: http://ic-iskra.ru/news/1989-myediatsiya-kak-sposob-uyeguli-ovaniya-konfliktov-voznikayushchikh-iz-p-avootnoshyeniy-v-oblasti-zd-avookh-anyeniya (дата обращения: 05.02.2021).

7. Развитие медицинского права и медиации. На вопросы главного редактора Пановой И.В. отвечает Бокерия Л.А.// Публичное право сегодня.-2020. - № 3.- С. 6-21.

8. Фастова М. А., Иванова Т. М. Теоретико-правовые аспекты посредничества с позиции функциональной теории// Вопросы экономики и права.-2019. - № 7 (133). - С. 22-29.

9. Хрестоматия по истории Древнего Рима. / Под ред. С. Л. Утченко. М.: Соцэкгиз, 1962.- С. 62-72.

10. Швец Е. Что такое медиация? Или как регулировать споры между медицинскими учреждениями и пациентами? // URL: https://vc.ru/legal/56761-chto-takoe-mediaciya-ili-kak-regulirovat-spory-mezhdu-medicinskimiuchrezhdeniyami-i-pacientami (дата обращения: 10.02.2021). 